\title{
KOMPARASI LAYANAN KULINER IKAN AIR TAWAR DI DESA WARUKAPAS KECAMATAN DIMEMBE KABUPATEN MINAHASA UTARA
}

\author{
Valennia Poliii'; Srie Sondakh2; Olvie Kotambunan² \\ 1)Mahasiswa Fakultas Perikanan dan IImu Kelautan Universitas Sam Ratulangi Manado \\ 2)Staff Pengajar Fakultas Perikanan dan IImu Kelautan Universitas Sam Ratulangi Manado \\ Koresponden email : poliivalennia@yahoo.com
}

\begin{abstract}
The purpose of this study was to identify a variety of culinary services and to know and analyze variables that affect consumer satisfaction in freshwater fish restaurants in Warukapas Village, Dimembe District, North Minahasa Regency. The basic method in this study is the survey method. The number of respondents is as many as 50 people divided into 25 respondents in Floating restaurants and 25 respondents in Dewe restaurant using Accidental sampling method, the type of data taken is primary data and secondary data then analysis using data processing applications (exel 2007) utilizing the Analysis Toolpak and Analysis Toolpak-VBA add-ins menus. The final results of data collection in the form of a complete picture of the problems presented in the form of data tables and variables analyzed quantitatively. The results of the research and discussion can be concluded: 1) Services provided to restaurants of freshwater fish are: guarantee of comfort, ideal service time, uniqueness of taste, completeness of facilities and combinations of complementary foods, 2) In general the results of the analysis show , complementary combinations of main foods and flavors in Floating and Dewe restaurants are not significantly different, but are seen from the restaurant service variables and the duration of service is significantly different, which is the RM service. Floating higher.
\end{abstract}

Keywords: Culinary Services, Freshwater Fish, Warukapas

\begin{abstract}
Abstrak
Tujuan penelitian ini adalah mengidentifikasi berbagai layanan kuliner dan mengetahui serta menganalisa variabel yang mempengaruhi kepuasan konsumen yang ada di rumah makan ikan air tawar Desa Warukapas Kecamatan Dimembe Kabupaten Minahasa Utara. Metode dasar dalam penelitian ini adalah metode survey. Jumlah responden adalah sebanyak 50 Orang yang terbagi masing-masing 25 responden di rumah makan Terapung dan 25 responden di rumah makan Dewe dengan menggunakan metode Accidental sampling, jenis data yang diambil adalah data primer dan data sekunder kemudian analisis menggunakan aplikasi pengolahan data (exel 2007) memanfaatkan menu add-ins Analysis Toolpak dan Analysis Toolpak-VBA. Hasil akhir pengumpulan data berupa gambaran lengkap permasalahan yang disajikan dalam bentuk table-tabel data dan variabel-veriabel yang dianalisis secara kuantitatif. Hasil penelitian dan pembahasan dapat disimpulkan : 1) Layanan yang diberikan pada rumah makan ikan air tawar yaitu : jaminan kenyamanan, waktu layanan yang ideal, keunikan cita rasa, kelengkapan fasilitas dan kombinasi pelengkap makanan, 2) Secara umum dari hasil analisis menunjukkan bahwa kelengkapan fasilitas, kombinasi pelengkap makanan utama dan cita rasa ada pada rumah makan Terapung dan Dewe tidak berbeda secara nyata, namun dilihat dari variabellayanan rumah makan dan lama waktu layanan berbeda nyata, hal mana layanan RM. Terapung lebih tinggí.
\end{abstract}

Kata kunci: Layanan Kuliner, Ikan Air Tawar, Warukapas.

\section{PENDAHULUAN}

Penelitian komparasi merupakan

penelitian yang dimaksudkan untuk mengetahui dan atau menguji perbedaan dua kelompok atau lebih. Penelitian komparasi juga adalah penelitian yang dilakukan untuk membandingkan suatu variabel (objek penelitian), antara subjek yang berbeda atau waktu yang berbeda dan menemukan hubungan sebabakibatnya. Metode komparasi adalah suatu metode yang digunakan untuk membandingkan data-data yang ditarik ke dalam konklusi baru. Komparasi sendiri dari bahasa inggris, yaitu compare, yang artinya membandingkan untuk menemukan persamaan dari kedua konsep atau lebih (Anonimous, 2019). Faktor-faktor penyebab adanya komparasi layanan di dalam suatu usaha yaitu : (1) Komparasi layanan rumah makan, (2) Komparasi lama waktu layanan, (3) Komparasi cita rasa, (4) Komparasi kelengkapan fasilitas, (5) Komparasi kombinasi makanan utama. 
Adapun tujuan dari penelitian komparasi adalah sebagai berikut: (1) membandingkan persamaan dan perbedaan dua atau lebih fakta-fakta dan sifat-sifat objek yang di teliti berdasarkan kerangka pemikiran tertentu, dan (2) membuat generalisasi tingkat perbandingan berdasarkan cara pandang atau kerangka berpikir tentu. (3) dapat menentukan mana yang lebih baik atau mana yang sebaiknya dipilih. (4) menyelidiki kemungkinan hubungan sebab-akibat dengan cara berdasar atas pengamatan terhadap akibat yang ada dan mencari kembali faktor yang mungkin menjadi penyebab melalui data tertentu (Anonimous, 2019).

Layanan atau service merupakan salah satu bagian penting dari suatu usaha sehingga tidak sedikit perusahaan yang memberikan pelatihan kepada para karyawan secara berkala untuk meningkatkan layanan kepada konsumen. Disadari bahwa pengaruh layanan pada penjualan sangat luar biasa, bahkan persaingan dengan competitor dalam hal harga bisa dimenangkan dengan layanan konsumen yang lebih memuaskan. Apalagi di era sekarang konsumen telah berubah menjadi semakin cerdas dan kritis karena faktor layanan menjadi hal yang sangat diutamakan (Anonimouns, 2015).

Pelayanan merupakan satu hal yang sangat penting dalam dunia bisnis karena pelayanan merupakan salah satu bentuk penghargaan kepada pelanggan. Pelayanan juga menjadi salah satu pertimbangan seseorang untuk memutuskan membeli produk atau menggunakan jasa dari sebuah perusahaan. layanan yang buruk bisa membuat pelanggan lari dan beralih keperusahaan pesaing. Mengingat begitu pentingnya pelayanan bagi kelangsungan suatu usaha, khusus pada usaha kuliner rumah makan ikan air tawar.

\section{METODE PENELITIAN}

Penelitian ini dilaksanakan di Kabupaten Minahasa Utara dengan menggunakan metode survey. Teknik pengumpulan data menggunakan metode Accidental Sampling yang berarti teknik penentuan sampel berdasarkan kebetulan atau incidental bertemu dengan peneliti dapat digunakan sebagai sampel, bila dipandang orang yang kebetulan ditemui itu cocok sebagai sumber data (Sugiono, 2009).

Jenis data yang diambil dalam penelitian ini meliputi data primer dan data sekunder. Data primer merupakan data yang diperoleh secara langsung dari lapangan yaitu data yang diperoleh dari responden (pengunjung) di lokasi rumah makan Terapung dan rumah makan Dewe dan melakukan wawancara secara langsung dengan menggunakan daftar pertanyaan yang sudah disediakan, sedangkan data sekunder adalah data-data yang di dapat dari instansi-instansi yang terkait. Kemudian Data hasil penelitian ini dianalisis dengan statistik uji $t$, yaitu membandingkan dua perlakuan yang berbeda (Rumah makan Terapung dan rumah makan Dewe), untuk melihat apakah kedua rumah makan ini sama ataukah berbeda dalam hal memberikan layanan kepada pengunjung atau konsumen. Analisis dengan statistik uji $t$ dilakukan menurut petunjuk Walpole (1995) sebagai berikut:

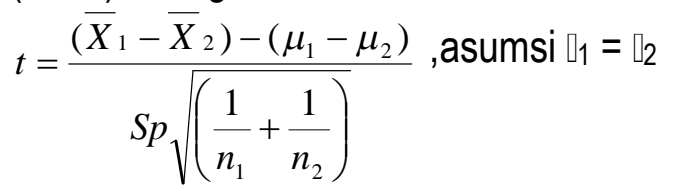


$S p^{2}=\frac{\left(n_{1}-1\right) S_{1}^{2}-\left(n_{2}-1\right) S_{2}^{2}}{n_{1}+n_{2}-2}$

$\mathrm{db}=\mathrm{n}_{1}+\mathrm{n}_{2}-2$ pada taraf nyata $\alpha=5 \%$.

Guna mempermudah analisis data digunakan aplikasi pengolah data (Excel 2007), memanfaatkan menu addins Analysis Toolpak dan Analysis Toolpak-VBA.

\section{HASIL DAN PEMBAHASAN}

\section{Awal Mula Berdirinya Rumah Makan Terapung}

Rumah makan Terapung (RM. Terapung), berdiri sejak tahun 2005 sampai sekarang dan Rumah makan ini diberi nama Terapung karena rumah makan ini berada terapung di atas telaga serta memiliki tenaga kerja sebanyak 9 orang.

Jenis-jenis ikan yang di sediakan dalam menu tersebut yaitu ikan mujair dan ikan mas dengan olahan kuliner yaitu di bakar, goreng, kuah asang, woku blanga dan pepes untuk jenis paket ikan mujair, dan untuk jenis paket ikan mas yaitu di bakar, goreng dan woku. Adapun Bumbu-bumbu, perlengkapan dapur dan ikan yang ada pada rumah makan Terapung di ambil dari pasar tradisional yaitu pasar Tatelu dan pasar Aermadidi. Jumlah pesanan pelanggan untuk setiap harinya pada kisaran hingga 150 paket.

jika pengunjung memesan 5 paket untuk setiap jenis olahan yang sesuai dengan selera pengujung maka pengunjung akan mendapat 1 bonus paket sesuai pilihan. Rumah makan terapung ini untuk hari senin sampai hari sabtu dibuka mulai dari pukul 09.00 pagi sampai pukul 22.00 malam sedangkan untuk hari minggu dibuka dari jam 14.00 siang sampai pukul 22.00 karena pada hari minggu adalah hari beribadah untuk orang Kristen.

Rumah makan Terapung adalah rumah makan yang paling banyak diminati oleh pelanggan karena tempat yang strategis.

\section{Awal Mula Berdirinya Rumah Makan Dewe}

Rumah makan Dewe (RM. Dewe) di Desa Warukapas Kecamatan Dimembe Kabupaten Minahasa Utara berdiri pada tahun 2011. Rencana dalam mendrikan usaha ini melalui kelompok agropolitan yang kemudian menjadi minapolitan jaya, modal untuk mendirikan rumah makan ini berawal dari kelompok tersebut. Rumah makan Dewe ini buka setiap harinya dari hari senin sampai Hari Minggu.

Jumlah tenaga kerja pada tahun 2011 baru berjumlah 5 orang. Semua tenaga kerja yang ada berasal dari daerah Likupang dan semua tenaga kerja yang bekerja harus tinggal di dalam rumah makan tersebut karena sudah di sediakan tempat tinggal untuk tenaga kerja. Seiring berjalannya waktu pada tahun 2012 jumlah tenaga kerja bertambah menjadi 16 orang sampai pada tahun 2019.

Rumah makan Dewe banyak di kenal oleh banyak masyarakat sehingga banyak pelanggan yang datang dari berbagai daerah untuk menikmati makanan yang ada pada rumah makan Dewe hampir setiap hari dapat menghabiskan 250 paket. Jenis-jenis menu ikan yang di sediakan berupa ikan mujair goreng, mujair bakar dan mujair woku blanga dan pepes. Melihat keadaan yang menguntungkan ini, maka pemilik rumah makan dewe mengeluarkan promo yaitu paket beli 5 gratis 1 agar lebih banyak lagi peminat karena dapat di lihat dari persaingan 
yang semakin banyak dan promo ini di buka mulai tahun 2014 sampai sekarang di tahun 2019.

Pada saat ini rumah makan Dewe selalu mengalami keuntungan, walaupun banyaknya persaingan yang ada di sekitar, tidak membuat para pelanggan untuk bosan datang ke tempat tersebut.

\section{Komparasi Layanan Rumah Makan}

Layanan Rumah makan adalah suatu kegiatan atau aktivitas yang dilakukan oleh Rumah Makan Terapung dan Rumah Makan Dewe. Pelayanan yang dimaksud ialah kepada konsumen atau pelanggan yang datang ke Rumah Makan tersebut. Layanan pada masingmasing rumah makan berbeda berdasarkan pengelolaan rumah makan. Berdasarkan statistic Uji $t$, didapat hasil layanan rumah makan Terapung berbeda nyata lebih tinggi dari pada layanan di rumah makan Dewe $(p<0,05)$.

\section{Komparasi Lama Waktu Layanan}

Lama waktu layanan adalah ketepatan waktu dimana kegiatan tersebut dapat di selesaikan atau lama waktu untuk melakukan sesuatu. sesuatu yang dimaksudkan ialah suatu hasil kegiatan yang dapat dicapai pada waktu yang di tetapkan tanpa lebih jam sedikitpun dengan mempengaruhi kualitas dan kuantitas suatu barang atau produk ataupun makanan. lama waktu layanan pada masing-masing rumah makan berbeda berdasarkan pengelolaan rumah makan. Berdasarkan statistic Uji t, didapat hasil lama waktu layanan rumah makan Dewe berbeda nyata lebih lama dibadingkan yang ada di rumah makan Terapung $(p<0,05)$.

\section{Komparasi Cita Rasa}

Cita rasa adalah suatu cara dalam pemilihan makanan yang harus dibedakan dari rasa (taste) makanan tersebut. cita rasa juga merpakan atribut makanan yang meliputi penampakan, bau, rasa, tekstur dan suhu. cita rasa juga dapat dikatakan sebagai suatu bentuk kerja sama dari kelima macam indra manusia yakni perasa,penciuman, perabaan,penglihatan dan pendengaran. Rasa itu sendiri merupakan hasil kerja dari pengecap rasa (Taste buds) yang terletak pada lidah, kerongkongan, atap mulut yang merupakan bagian dari cita rasa. Cita rasa pada masing-masing rumah makan berbeda berdasarkan pengelolaan rumah makan. Berdasarkan statistic Ujict, didapat hasil Cita rasa rumah makan Terapung tidak berbeda nyata jika dibadingkan yang ada di rumah makan Dewe $(p>0,05)$.

\section{Komparasi Kelengkapan Fasilitas}

Dalam setiap rumah makan harus tersedia perlengkapan dalam jumlah yang memadai yang akan menunjang kelancaran operasional di rumah makan, serta akan mempunyai mutu dan penampilan yang baik karena citra rumah makan dapat di bangun memalui kualitas perlengkapan dan peralatan yang disediakan. Suatu rumah makan yang tidak memiliki perlengkapan dan peralatan tidak bisa memenuhi kebutuhan makanan dan minuman utuk konsumen atau pengunjung. agar kualitas pelayanan tetap terjaga dengan baik, pihak rumah makan harus memeperhatikan peralatan serta perlengkapan yang disediakan seperti meja, kursi, stand atau pondok, perlengkapan meja di antaranya sendok, garfu, gelas, dan lain-lain sebagainya yang berkaitan deng perlengkapan makan. 
Sesuai dengan struktur organisasi rumah makan, maka setiap karyawan atau pekerja memiliki tanggung jawab dan jenis pekerjaannya masing-masing. kelengkapan fasilitas pada masing-masing rumah makan berbeda berdasarkan pengelolaan rumah makan. Berdasarkan statistic Uji t, didapat hasil kelengkapan fasilitas rumah makan Dewe tidak berbeda nyata jika dibadingkan yang ada di rumah makan Terapung $(p>0,05)$.

\section{Komparasi Kombinasi Pelengkap Makanan Utama}

Menu adalah daftar makanan yang disajikan kepada pengunjung yang ada pada rumah makan. setiap rumah makan memiliki cara-cara tersendiri dalam menyusun menu, akan tetapi pada dasarnya sama yaitu untuk membuat para konsumen atau pengunjung menjadi tertarik untuk memesan makanan. setiap pengunjung mengenal jenis makanan ringan yang di nikmati sebagai hidangan pembuka atau penutup yang dapat digolongkan sebagai makanan pelengkap seperti kripik, pudding, jus dan jenis-jenis minuman lainnya. jenis-jenis kombinasi makanan utama disetiap rumah makan berbeda-beda sesuai dengan perubahan tingkat hidup konsumen sehingga ada jenis menu pelengkap yang lebih modern. Kombinasi pelengkap makanan utama pada masing-masing rumah makan berbeda berdasarkan pengelolaan rumah makan. Berdasarkan statistic Uji t, didapat hasil kelengkapan fasilitas rumah makan Dewe tidak berbeda nyata jika dibadingkan yang ada di rumah makan Terapung $(p>0,05)$.

\section{KESIMPULAN}

Hasil penelitian dan pembahasan dapat disimpulkan :

1. Layanan yang diberikan pada rumah makan ikan air tawar yaitu : jaminan kenyamanan, waktu layanan yang ideal, keunikan cita rasa, kelengkapan fasilitas dan kombinasi pelengkap makanan.

2. Secara umum dari hasil analisis menunjukkan bahwa kelengkapan fasilitas, kombinasi pelengkap makanan utama dan cita rasa ada pada rumah makan Terapung dan Dewe tidak berbeda secara nyata, namun dilihat dari variabel layanan rumah makan dan lama waktu layanan berbeda nyata, hal mana Jayanan RM. Terapung lebih tinggi.

\section{DAFTAR PUSTAKA}

Beerli, A., Martin, J.D., \& Quintana, A. 2004.

A Model of Customer ARYANI,
PENGARUH KUALITAS LAYANAN
TERHADAP KEPUASAN
PELANGGAN 126 Loyalty in The Retail
Banking Market. European Journal of
Marketing, 38.

Caruana, A. 2002. Service Loyalty The Effects of Service Quality andThe Mediating Role of Customer Satisfaction. European Journalof Marketing, 36 .

Dahlan, Alwi, dkk. 1995. Kamus Besar Bahasa Indonesia. Jakarta: Balai Pustaka.

Daniel, M, 2003. Metodologi Penelitian Sosial Ekonomi. Edisi Kedua. Bumi Angkasa. Jakarta.

Menteri Negara Koordinator Pengawasan Pembangunan dan Pendayagunaan Aparatur Negara. 1998. Surat Edaran Menko Wasbangpan Nomor 56/MK.WASBANGPAN 6/98 Tahun 1998 Tentang Penataan dan Perbaikan Pelayanan Umum. Jakarta. 
Menteri Negara Pendayagunaan Aparatur Negara. 2003. Surat Keputusan Menteri Negara Pendayagunaan Aparatur Negara Nomor 63 Tahun 2003 Tentang Pedoman Tata Laksana Pelayanan Umum. Jakarta.

Lupiyoadi, 2006. Rancangan Pelayanan Publik. Jakarta.
Normann, 1991. Service Management. Chicester, England: Wiley \& Son.

Sutopo dan Suryanto, A., 2003. Pelayanan Prima. Jakarta: Lembaga Administrasi Negara Republik Indonesia. 